\title{
Parents' Marital Status and Psychological Distress among College Students
}

\section{Lavenda Geshica $^{\mathrm{a}}$ and Sugiarti Musabiq ${ }^{\mathrm{b}}$}

$a_{\text {Faculty of Psychology, Universitas Indonesia, Depok, Indonesia; }}{ }^{b}$ Department of Clinical Psychology, Faculty of Psychology, Universitas Indonesia, Depok, Indonesia

*Corresponding author:

Sugiarti Musabiq

Department of Clinical Psychology

Faculty of Psychology, Universitas Indonesia

Jl. Lkr. Kampus Raya, Depok, Jawa Barat

Indonesia, 16424

Tel.: +62 217270004

Email address: sugiarti@ui.ac.id 


\title{
Parents' Marital Status and Psychological Distress among College Students
}

\begin{abstract}
The main objective of the recent study was to explore the association between parents' marital status and psychological distress in college student. The sample consisted of 1024 students from various colleges in Indonesia (297 men and 727 women). Psychological distress was measured by the Bahasa Indonesia version of Hopkins Symptom Checklist-25 (HSCL-25). The result of descriptive statistics proved that most of the participants had high psychological distress. Participants raised by married parents tend to have lower psychological distress than participants raised by widowed or divorced parent(s). The analysis of each aspect showed that participants raised by widowed parent had higher anxiety than participants raised by married parents. Meantime, participants raised by divorced parents had higher depression compared to participants raised by married parents. It also indicated the interactions between gender, parent's marital status, and psychological distress. These findings could be reference for academic counselor to enforce a prevention program for college students who may suffer from high psychological distress, especially for college students who raised in divorced or widowed families.
\end{abstract}

Keywords: College Student, HSCL-25, Parents' Marital Status, Psychological Distress

\section{Introduction}

Suicide is the worst manifestation of psychological distress people experience (Eskin et al., 2016). According to the World Health Organization (2014), at least 800,000 people died by suicide every year. Moreover, worldwide, suicide is the second highest cause of death in people aged 15-29 years. In Indonesia, the suicide rate of people aged 15-29 years old is 3.9 per 100,000 people. This high rate of death by suicide implies the need for suicide prevention programs. Therefore, issues about suicide have been included in the mental health action plan target to reduce the number of deaths due to suicide by $10 \%$ in 2020 (WHO, 2014).

According to Lazarus and Folkman (1948, p.19) psychological distress is defined as "a particular relationship between the person and the environment that is appraised by the person as taxing or exceeding his or her resources and endangering his or her well-being". Each developmental stage of life carries a different risk of psychological distress. College students who are in the emerging adulthood developmental stage have a higher risk of psychological distress compared to other populations (Curtis, 2010). This is because they face several transitions, such as the transition from high school to college and the transition from adolescence to early adulthood (Arnett, 2013; Curtis, 2010; Sugiarti, Geshica, Prabowo, Rachmawati, Alkarisya, \& Mulyaningrum, 2018). These transitions may lead to psychological problems including loneliness, isolation, and identity loss (Curtis, 2010). Moreover, college students nowadays have a higher risk of psychological distress compared to their counterparts 15-20 years ago due to several factors such as the rising of tuition fees leading to financial problems, increasing demand for academic success, and highly competitive employment market contributing to difficulty finding a job (Sharkin, 2013; Sugiarti et al., 2018). 
Although in general college students experience various problems and pressures, not all of them have a high level of psychological distress. It is because psychological distress is a complex phenomenon caused by numerous factors. Sugiarti et al. (2018) showed that family disfunction, personality traits (high level of neuroticism and low level of extraversion), low optimism, low resilience, and lack of social support could contribute to psychological distress.

Other studies showed that parents' marital status can be salient risk factor of psychological distress. According to Turley and Desmond (2011), those from divorced or widowed parent(s) only had one or no parental figure living with them. These conditions forced them to grow up faster, be less dependent, and learned to take care of themselves. Moreover, they had greater burdens such as having housework responsibilities and taking part-time jobs to improve their family's financial condition.

Hayatbakhsh, Clavarino, Williams, Bor, Callaghan, and Najman (2013) investigated the association between parents' marital status and psychopathology. This longitudinal study lasted for 21 years with four times follow-up (6 months, 5 years, 4 years, and 21 years). Marital status and marital quality were assessed at the 14- year follow-up. In the 21-year follow-up participants were asked to fill out the Young Adult Self-Report sub-scales of a mental health and problem behavior questionnaire. The results showed that children who lived with a step-father, unpartnered mother, or in a family where the parents had conflict had a higher level of psychopathology at 21-year follow-up (Hayatbakhsh et al., 2013). Similar results were seen in Pappa (2013), where those from divorced families had poorer academic performance and had more internalizing and externalizing behavior.

According to the phenomena that have been described, it is important to conduct a study explaining the association between parents' marital status and psychological distress in the Indonesian college student population. We begin this study with an introduction to the association between parents' marital status and psychological distress. The next section describes the study methods. This is followed by a presentation of the results and a discussion.

\section{Methods}

\section{Participants}

A total of 1,024 college students from several colleges in Indonesia (297 males, 727 females) participated in this study. Non-probability sampling (convenience sampling) was used to select the participants from the population. The age range was 18-25 years old. Most of the participants were pursuing a bachelor's degree. All were Indonesian and knew both oral and written Bahasa Indonesia (Sugiarti et al., 2018).

\section{Measure}

The Bahasa Indonesia version of Hopkins Symptom Checklist-25 (HSCL-25) was a 25-item self-report scale used to measure participants' level of psychological distress. HSCL-25 consisted of two aspects, anxiety (10 items) and depression (15 items). Each item was rated 
on a four-point Likert-scale, from 1 "not at all" to 4 "extremely". The Cronbach's alpha reliability of HSCL-25 used in the study was 0.913 (Sugiarti et al., 2018).

\section{Procedure}

A paper-and-pencil questionnaire (traditional) and web-based questionnaire (Google Form) were used to collect the data. They consisted of background information about the purpose of the study, informed consent, participants' demographic profile, and HSCL-25. The data were analyzed using descriptive statistics and analysis of variance (ANOVA). All participants who filled out the traditional questionnaire were given a pen and a notebook. Five randomly chosen participants who completed the web-based questionnaire received an IDR 100,000 mobile recharge (approximately 7.5 US\$) (Sugiarti et al., 2018).

\section{Results}

\section{Participants' Characteristics}

Table I. Participants' Characteristics
\begin{tabular}{|c|r|r|}
\hline Characteristics & \multicolumn{1}{|c|}{ F } & \multicolumn{1}{c|}{$\%$} \\
\hline Sex & & \\
1. Male & 297 & 29.00 \\
2. Female & 727 & 71.00 \\
\hline Age & & \\
1. 18 years' old & 123 & 12.00 \\
2. 19 years' old & 210 & 20.50 \\
3. 20 years' old & 294 & 28.70 \\
4. 21 years' old & 266 & 26.00 \\
5. 22 years' old & 100 & 9.80 \\
6. 23 years' old & 12 & 1.20 \\
7. 24 years' old & 11 & 1.10 \\
8. 25 years' old & 8 & 0.80 \\
\hline Parents' Marital Status & & \\
1. Married & 892 & 87.10 \\
2. Divorced & 53 & 5.20 \\
3. Widowed & 79 & 7.70 \\
\hline
\end{tabular}

As Table I shows, the study participants were 1,024 college students from several colleges in Indonesia. Among them, 553 participants filled out the traditional questionnaire, but 186 questionnaires were excluded from the analysis because they were not complete. Meanwhile, 662 participants filled out the web-based questionnaire, but 5 of the 662 questionnaires were excluded because the participants did not meet the research criteria. The age range of the participants was 18-25 years $(M=20.13, \mathrm{SD}=1.34)$. The gender distribution was $297(29 \%)$ men and 727 (71\%) women (Sugiarti et al., 2018). In terms of parents' marital status, 87.1\% of the participants were raised by married parents, $5.20 \%$ were raised by divorced parents, and $7.7 \%$ were raised by a widowed parent. 


\section{Descriptive Statistics}

Table II. Level of Psychology Distress

\begin{tabular}{|c|c|c|c|}
\hline & Frequency & Valid Percent & Cumulative Percent \\
\hline Low & 336 & 32.8 & 32.8 \\
\hline High & 688 & 67.2 & 100.0 \\
\hline Total & 1024 & 100.0 & \\
\hline
\end{tabular}

Descriptive statistics were used to see the participants' level of psychological distress. According to Table II, 336 (32.8\%) participants had low psychological distress and 688 $(67.2 \%)$ participants had high psychological distress. Therefore, most of the participants had a high level of psychological distress.

\section{Analysis of Variance (ANOVA)}

Table III. Psychological Distress and Parents' Marital Status

\begin{tabular}{|l|c|c|}
\hline & F & Sig. \\
\hline Between Groups & 5.285 & 0.005 \\
\hline Within Groups & & \\
\hline
\end{tabular}

One-way ANOVA was used to see the difference of psychological distress between three groups of participants. Table III proved that there was significant difference of psychological distress between participants raised by married, divorced, and widowed parents $(\mathrm{F}=5.285, \mathrm{p}<0.01)$.

Table IV. Post-Hoc Analysis of Psychological Distress and Parents' Marital Status

\begin{tabular}{|c|c|c|c|}
\hline $\begin{array}{c}\text { (I) Parents' } \\
\text { Marital Status }\end{array}$ & $\begin{array}{c}\text { (J) Parents' } \\
\text { Marital Status }\end{array}$ & $\begin{array}{c}\text { Mean } \\
\text { Difference } \\
(\mathrm{I}-J)\end{array}$ & Sig. \\
\hline & Divorced & $-0.17276^{*}$ & 0.022 \\
\hline Married & Widowed & $-0.15362^{*}$ & 0.014 \\
\hline & Married & $0.17276^{*}$ & 0.022 \\
\hline Divorced & Widowed & 0.01914 & 0.840 \\
\hline & Married & $0.15362^{*}$ & 0.014 \\
\hline Widowed & Divorced & -0.01914 & 0.840 \\
\hline
\end{tabular}

Table IV shows the post-hoc analysis of psychological distress and parents' marital status. As the tables shows, the participants raised by divorced parents had higher psychological distress compared to those raised by married parents $(t=0.173, p<0.05)$. The participants raised by widowed parents also had higher psychological distress compared to participants raised by married parents $(t=0.15362, p<0.05)$. However, there was no significant difference of psychological distress between the participants raised by divorced and widowed parents $(\mathrm{t}=0.1914, \mathrm{p}>0.05)$. 
Table V. Post-Hoc Analysis of Anxiety and Parents' Marital Status

\begin{tabular}{|c|c|c|c|}
\hline $\begin{array}{c}\text { (I) Parents' } \\
\text { Marital Status }\end{array}$ & $\begin{array}{c}\text { (J) Parents' } \\
\text { Marital Status }\end{array}$ & $\begin{array}{c}\text { Mean } \\
\text { Difference } \\
(\mathrm{I}-\mathrm{J})\end{array}$ & Sig. \\
\hline & Divorced & -0.53970 & 0.542 \\
\hline Married & Widowed & $-1.95432^{*}$ & 0.008 \\
\hline & Married & 0.53970 & 0.542 \\
\hline Divorced & Widowed & -1.41462 & 0.204 \\
\hline & Married & $1.95432^{*}$ & 0.008 \\
\hline Widowed & Divorced & 1.41462 & 0.204 \\
\hline
\end{tabular}

We also did further analyses to find out the association between parents' marital status and two aspects of psychological distress (anxiety and depression). Table $\mathrm{V}$ shows that the participants raised by widowed parents had higher anxiety than those raised by married parents $(\mathrm{t}=1.954, \mathrm{p}<0.01)$.

Table VI. Post-Hoc Analysis of Depression and Parents' Marital Status

\begin{tabular}{|c|c|c|c|}
\hline $\begin{array}{c}\text { (I) Parents' } \\
\text { Marital Status }\end{array}$ & $\begin{array}{c}\text { (J) Parents' } \\
\text { Marital Status }\end{array}$ & $\begin{array}{c}\text { Mean } \\
\text { Difference } \\
(\mathrm{I}-J)\end{array}$ & Sig. \\
\hline & Divorced & $-3.77936^{*}$ & 0.001 \\
\hline Married & Widowed & -1.88612 & 0.054 \\
\hline & Married & $3.77936^{*}$ & 0.001 \\
\hline Divorced & Widowed & 1.89324 & 0.201 \\
\hline & Married & 1.88612 & 0.054 \\
\hline Widowed & Divorced & -1.89324 & 0.201 \\
\hline
\end{tabular}

Meanwhile, as Table VI shows, the six participants raised by divorced parents showed higher levels of depression than those raised by married parents $(t=3.780, p<0.01)$.

Table VII. Interaction between Sex, Parents' Marital Status, and Anxiety

\begin{tabular}{|c|c|c|c|c|}
\hline Sex & $\begin{array}{c}\text { (I) Parents' } \\
\text { Marital } \\
\text { Status }\end{array}$ & $\begin{array}{c}\text { (J) Parents' } \\
\text { Marital } \\
\text { Status }\end{array}$ & $\begin{array}{c}\text { Mean } \\
\text { Difference (I-J) }\end{array}$ & Sig. ${ }^{b}$ \\
\hline \multirow{6}{*}{ Males } & \multirow{2}{*}{ Married } & Divorced & -0.618 & 0.671 \\
\hline & & Widowed & -1.724 & 0.259 \\
\hline & \multirow{2}{*}{ Divorced } & Married & 0.618 & 0.671 \\
\hline & & Widowed & -1.106 & 0.587 \\
\hline & \multirow{2}{*}{ Widowed } & Married & 1.724 & 0.259 \\
\hline & & Divorced & 1.106 & 0.587 \\
\hline \multirow{6}{*}{ Females } & \multirow{2}{*}{ Married } & Divorced & -0.618 & 0.580 \\
\hline & & Widowed & $-1.950^{*}$ & 0.020 \\
\hline & \multirow{2}{*}{ Divorced } & Married & 0.618 & 0.580 \\
\hline & & Widowed & -1.332 & 0.325 \\
\hline & \multirow{2}{*}{ Widowed } & Married & $1.950^{*}$ & 0.020 \\
\hline & & Divorced & 1.332 & 0.325 \\
\hline
\end{tabular}


To generate more comprehensive data, we tried to find the interaction between sex, parents' marital status, and two aspects of psychological distress through a two-way ANOVA. Table VII shows that the female participants raised by widowed parents had higher anxiety compared to female participants raised by married parents $(t=1.950, p<0.05)$.

Table 8. Interaction between Sex, Parents' Marital Status, and Depression

\begin{tabular}{|c|c|c|c|c|}
\hline Sex & $\begin{array}{c}\text { (I) } \\
\text { Parents' } \\
\text { Marital } \\
\text { Status }\end{array}$ & $\begin{array}{c}(\mathrm{J}) \\
\text { Parents' } \\
\text { Marital } \\
\text { Status }\end{array}$ & $\begin{array}{c}\text { Mean } \\
\text { Difference } \\
(\mathrm{I}-\mathrm{J})\end{array}$ & Sig. ${ }^{b}$ \\
\hline \multirow{6}{*}{ Males } & \multirow{2}{*}{ Married } & Divorced & -0.897 & 0.642 \\
\hline & & Widowed & $-4.459^{*}$ & 0.028 \\
\hline & \multirow{2}{*}{ Divorced } & Married & 0.897 & 0.642 \\
\hline & & Widowed & -3.561 & 0.187 \\
\hline & \multirow{2}{*}{ Widowed } & Married & $4.459^{*}$ & 0.028 \\
\hline & & Divorced & 3.561 & 0.187 \\
\hline \multirow{6}{*}{ Females } & \multirow{2}{*}{ Married } & Divorced & $-5.612^{*}$ & 0.000 \\
\hline & & Widowed & -1.077 & 0.334 \\
\hline & \multirow{2}{*}{ Divorced } & Married & $5.612^{*}$ & 0.000 \\
\hline & & Widowed & $4.535^{*}$ & 0.012 \\
\hline & \multirow{2}{*}{ Widowed } & Married & 1.077 & 0.334 \\
\hline & & Divorced & $-4.535^{*}$ & 0.012 \\
\hline
\end{tabular}

According to Table VIII, male participants raised by widowed parents had higher depression than male participants raised by married parents $(t=4.459, p<0.05)$. Female participants raised by divorced parents had higher depression compared to female participants raised by married parents $(\mathrm{t}=5.612, \mathrm{p}<0.01)$. Female participants raised by divorced parents had higher depression than female participants raised by widowed parents $(\mathrm{t}=4.535, \mathrm{p}<0.05)$.

\section{Discussion and Conclusion}

The objective of the recent study was to investigate the association between parents' marital status and psychological distress. The results of descriptive statistics proved that most of the participants had high psychological distress. This supports the assumption that college students are more prone to experience high psychological distress.

Through ANOVA, we found that the participants raised by married parents tended to have lower psychological distress than those raised by divorced or widowed parents. This finding is in line with Turley and Desmond's (2011) study in which those raised by divorced or 
widowed parents only had one or no parental figure living with them. These conditions forced them to grow up faster, be less dependent, and learn to take care of themselves. Furthermore, they had greater burdens such as having housework responsibilities and taking part-time jobs to improve their family's financial condition.

Hovey and Seligman (2007) found that proper family support can be a protective factor of anxiety and depression. Moreover, Taylor (2008) explained that adequate family support makes people feel loved, respected, and cared for. Although having married parents does not guarantee proper family support, those raised by married parents had a higher probability of having adequate social support from their family.

We realize that the present study has several limitations. For example, we did not ask the participants from divorced parents when their parents divorced or which parent they lived with after the separation. Similarly, we did not ask the participants with widowed parents when one parent died or whether the it was the father or mother who passed away. Nonetheless, the study findings may serve as a reference for academic counselors to implement prevention programs for college students who may suffer from high psychological distress, especially for those raised by divorced or widowed parents.

\section{References}

Arnett, J.J. (2013). Adolescence and emerging adulthood: a cultural approach. New Jersey: Pearson.

Chung, Y., \& Emery, R. (2010). Early adolescents and divorce in South Korea: Risk, resilience and pain. Journal of Comparative Family Studies, 855-870.

Curtis, C. (2010). Youth perceptions of suicide and help-seeking: They'd think I was weak or "mental". Journal of Youth Studies, 13(6), 699-715.

Eskin, M., Sun, J. M., Abuidhail, J., Yoshimasu, K., Kujan, O., Janghorbani, M., \& Hamdan, M. (2016). Suicidal behavior and psychological distress in university students: a 12- nation study. Archives of Suicide Research, 1-20.

Hayatbakhsh, R., Clavarino, A. M., Williams, G. M., Bor, W., O’Callaghan, M. J., \& Najman, J. M. (2013). Family structure, marital discord and offspring's psychopathology in early adulthood: a prospective study. European child \& adolescent psychiatry, 22(11), 693-700.

Hovey, J.D., \& Seligman, L.D. (2007). Religious coping, family support, and negative affect in college students. Psychological Reports, 100(3), 787-778. doi: 10.2466/pr0.100.3.787-788

Lazarus, R., \& Folkman, S. (1984). Stress, appraisal, and coping. New York: Springer Publishing Company.

Pappa, V (2013). Relationships between Parents' Marital Status and the Psychological Well-being of Adolescents in Greece. Journal of Psychology \& Psychotherapy, 3(2), 1.

Sharkin, B. (2013). College students in distress: A resource guide for faculty, staff, and campus community. New York: Routledge.

Sugiarti, Geshica, L., Prabowo, D. A., Rachmawati, A., Alkarisya, A., \& Mulyaningrum, V. A. (2018). Ups and Downs as Indonesian College Students: Risk and Protective Factors for Psychological Distress. In Applied Psychology Readings (pp. 281-293). Springer, Singapore.

Taylor, S. (2008). Health psychology ( $8^{\text {th }}$ ed). New York: McGraw Hill.

Turley, R. N., \& Desmond, M. (2011). Contributions to college costs by married, divorced, and remarried parents. Journal of Family Issues, 32(6), 767-790.

World Health Organization. (2014). Preventing suicide: a global imperative. World Health Organization. 